\title{
Use of visual technologies in the development of digital literacy of University teachers
}

\author{
Oksana Kholina $^{1, *}$,Elena Kornienko ${ }^{2}$, Tatiana Buyndyugova ${ }^{3}$ \\ ${ }^{1}$ Taganrog Institute named after A. P. Chekhov (branch) RSEU (RINH), Russia \\ ${ }^{2}$ Taganrog Institute of management and economy, Russia \\ ${ }^{3}$ Southern University (IMBL), Russia
}

\begin{abstract}
The article contains the results of research on the use of visualization in the training of University teachers (development of digital literacy). The paper describes the concept of visualization, its main levels (visualization of data, information, knowledge), briefly describes the proposed course, assessment parameters before and after participation, and summarizes the results of the study. The paper also reflects the results of a survey of students who study with these teachers and heads of educational organizations in order to identify possible changes in the professional activities of teachers who have completed the proposed course. The results of the study confirmed the effectiveness of using visualization in improving the quality of professional activity of teachers, and significant differences were found in the assessment of teachers ' attitude to innovation and work in the digital environment before and after the course. According to the results of the study, the features of the use of visual technologies in the training of teachers and the development of their digital literacy were highlighted.
\end{abstract}

\section{Introduction}

Modern digitalization of the educational process has allowed us to identify a list of areas that need to be optimized in the first place. As part of the surveys (219 people in total) conducted at a number of higher educational institutions in the Rostov region, it was revealed that $78 \%$ of the surveyed teachers are ready to learn new digital technologies, while $100 \%$ of the surveyed teachers experience stress and negative emotions due to a vague understanding of the possibilities of digital technologies, difficulties in their development and systematic use.

In connection with the results obtained, as well as on the basis of the current situation, it became necessary to develop a number of measures, primarily of a psychological nature, to increase the productivity of teachers in working with digital technologies, and to form internal motivation for working in the digital space. Without timely training of teachers, it is impossible to implement innovations and increase the competitiveness of the University.

As part of training teachers to use digital technologies and work in an electronic educational environment, training seminars based on visualization were held.

\footnotetext{
* Corresponding author: xseny@mail.ru
} 
The focus on visual representation of information in the process of educational activity is currently explained by the fact that the applied teaching technologies must adequately, accurately, and most importantly, interestingly reflect the results of research, applied developments, and scientific innovations that appear in a large number of modern educational fields. It is visualization that will help to form and maximize the interest of students in obtaining knowledge and developing professional competencies.

Visualization allows you to present various amounts of information in the form of images in order to maximize their assimilation. In the theory of schemes of R. S. Anderson and F. Bartlett, visualization is described as a process of active cognitive activity that allows you to transform mental images from the internal plane of consciousness to the external one. A.A. Verbitsky describes visualization as the transformation of mental images into visual images that, when actively perceived, can unfold and contribute to rapid and accurate thinking and practical actions [6].

G.V. Lavrentiev and N.E. Lavrentieva proposed the term "technology of visualization of educational information". They view visualization as symbolic, but also as images of "visualization", which can dominate depending on the subject of analysis and study (points, shapes, tones, lines, colors, sizes) [8].

Visualization is primarily aimed at compressing the volume of data being studied and presenting them in the form of dynamic or static mental images depicted schematically $(\mathrm{V}$. V. Davydov's theory of content generalization, P.M. Erdniev's theory of enlargement of didactic units) [debris].

Visualization can be described at three main levels: data visualization (demonstration of a set of information), then information (reflection of data in chronology and space), and finally knowledge (transformation of information in order to systematize and rethink it) (G. Caviglia, L. Masud, Fr. Valsecchi) [4].

Visualization focuses on the active, conscious use of images associated with educational information, it always affects the psychological processes of reflection and display [5]. This is always an active work and interaction with the educational material. It is also defined as an" epistemological mechanism " - an intermediate link between the data being studied and the result of this training, which eliminates secondary details [3].

Thus, visualization allows you not only to present data in a more convenient format, but also to assimilate and remember them as much as possible, and make them part of your internal picture of the world.

\section{Materials and methods results}

As part of the training of University teachers to work with digital technologies, a practical course was developed based on visualization and semantic impact - that is, all information was maximally encoded and transformed into images by the course participants themselves, and all technologies were "filtered" - teachers answered "why" and "how" they would use these technologies, "what" benefits they would bring to them in their work.

The structure of the course included only practical classes, which began with the distribution of technological visual maps, which they studied independently, then they answered the questions listed above, and then in practice they worked out all the knowledge they had mastered in active work specifically in the field of taught courses. Each session started with a psychological activation warm-up and ended with a little resource practice and compliments on each other's results. All work on the course was individual in nature. The audience included a technical consultant and a psychologist. Music therapy was also used (light relaxing music was always played in the background to relieve tension and activate the right hemisphere). 
Prior to the implementation of the course, a survey was conducted, which included an assessment of several parameters (from 0 to 5 points):

- attitudes to innovation;

- attitude to work in the digital environment;

- self-assessment of information literacy growth;

- the level of application of innovations and creative tasks in the courses read.

As a result of the course implementation, two more measurements were made: immediately after the end of classes and after 3 months.

The study involved 118 teachers aged 36 to 53 years, with at least 5 years of experience in higher education.

The course program was designed for 20 hours of classes -5 days of 4 hours and included 5 main blocks:

1. digital space: what is It? The participants discussed current research, considered the features of education in the digital environment and the possibilities of digital space for teachers in order to facilitate their work and increase its effectiveness.

2. Using cognitive graphics in your work. The participants discussed the possibilities of presenting interesting data in their classes and in interaction with students.

3. Teaching cognitive graphics to your students in the course of classes. The advantages of working with figurative information, its assimilation and understanding by students were discussed and demonstrated here.

4. Developing a personal brand in the digital space. The participants discussed the possibilities and necessity of self-presentation and reflection of their work results in the digital environment.

5. Use of various software to improve the effectiveness of teachers. Here discussed the program of the presentation of the data, video editing, database compilation, etc. Many things were prepared right before classes, based on the requests of teachers.

The model of using visualization in the course was as follows: presentation of the theoretical block using visual graphics, working out in practice in accordance with the requests of teachers using cognitive maps of the most complex issues. All the teachers ' suggestions and questions were also presented using coding technology (all key questions were represented using symbols). The main goal is to teach you how to collapse a large amount of information into mental images that will help you work with it in the future.

\section{Results}

A) the results of a survey of teachers before and after the course made it possible to analyze in detail the changes that occurred in the participants:

1. As for the attitude to the innovation policy of educational organizations, participants after the course became more willing to cooperate and use innovations in their professional activities than it was before participating in the course. Perhaps this is due to the emergence of interaction skills, more information about the digital space, after analyzing the information received. The differences are significant $(\mathrm{Uemp}=0.125)$, at a significance level of 0.01 .

2. The study of teachers' attitude to work in a digital environment showed that participants still prefer to work "face to face", but at the same time they began to perceive work in a digital environment more calmly and use it more often. The differences are significant (Uemp= 0.114 ), the significance level is 0.01 .

3. The indicators of teachers' assessment of the level of their digital literacy have Changed, its individual parameters have become, in their opinion, higher: the ability to use digital technologies $(\mathrm{Uemp}=0.229)$, knowledge of the functioning of the digital space $(\mathrm{Uemp}=0.192)$, as well as adaptation to the digital environment in General (Uemp=0.133). Participants became more accepting of various digital technologies and experienced more 
emotional comfort when working in a digital environment. The differences are significant at a significance level of 0.01 .

4. After the implementation of the program, internal motivation became higher. This can be explained by a greater awareness of the importance of digital technologies in the work and their use, a clearer understanding of possible areas of professional development. The differences are significant (Uemp=0.104), the significance level is 0.01 .

5. Changes were identified in the number of innovations $(\mathrm{Uemp}=0.123)$ and creative tasks $($ Uemp $=0.207)$ in the subjects taught by teachers. The differences are significant at a significance level of 0.01 .

B) in Addition, according to the data of free-form interviews of students in General about the features of teaching, the quality of their assimilation of information within the disciplines, they noted $86 \%$ more teachers who completed this course. They were described as" competent"," competent "and" very interesting "teachers who" explain everything simply and easily. These teachers are more trustworthy, and students listen to them more.

All these data can significantly positively influence the use of teachers ' authority in educational work, on the one hand. On the other hand, satisfied and well-trained students are translators of the positive image of the University and various areas and levels of training in it.

C) Interviewing managers from educational organizations (deans of faculties were interviewed) showed that they note the level of professional growth of teachers who completed the course in $89 \%$, the growth of their initiative in $64 \%$, and self-presentation skills in $72 \%$.

All this allows us to speak about the effectiveness of using visualization in teaching higher school teachers.

\section{Discussion}

The significance of the data obtained confirms the goals set at the beginning of the study-to confirm the effectiveness of using visualization in teaching University teachers. The data obtained confirmed the results obtained in previous studies (the use of visualization in training employees of commercial organizations, in working with stress, with various clinical disorders: anxiety, burnout syndrome).

The value of the data obtained in confirming various theoretical positions of I.V. Abakumova (on semantic components of visualization), I.V. Avdulova (on technical components of using data visualization), R. Arnheim (on visual thinking), B.M. Velichkovsky (on cognitive mechanisms), V.P. Zinchenko and N.Yu. Vergiles (on the structure of the visual image).

The results of the study, on the one hand, expanded the idea and confirmed the data that visualization is a technology of active perception and presentation of data, on the other hand, allowed us to outline the research trend: to analyze the possibilities of using visualization in the development of motivation, impact on the audience and use in the construction of semantic connections.

\section{Conclusion}

The use of visual technologies in the practice of teaching higher school teachers has shown that:

- these technologies change the attitude of teachers to the implemented innovations;

- visualization allows you to look at the subjects taught and plan your work from a different angle; 
- visualization makes work easier and faster, thereby helping to strengthen internal motivation in professional activities;

- thanks to visualization, the course was completed easily by teachers and, as a result, they note a significant increase in digital literacy and the desire to work in a digital environment;

- visualization also allowed teachers to find interesting and creative approaches to the presentation of materials in their courses.

In General, the use of visualization in the training of adults, especially those who are not inclined to accept innovations in professional activities, conservative, contributes to emancipation, reducing stress and increasing the willingness to develop in work.

Visualization of information and knowledge contributes not only to their optimal and effective assimilation, but also to their inclusion in the internal picture of the world of the individual, which increases awareness, critical study of all perceived data, their filtering through values and meanings. In addition, visualization facilitates the transfer of information and knowledge from person to person, allows them to rally around an idea or project at a high psychological and social level, which is one of the key factors for effective work of teachers and improving the competitiveness of the University.

\section{References}

1. I.V. Abakumova, P.N. Ermakov, E.A. Makarova, Skhema i fon: introekciya v neodnorodnom semioticheskom prostranstve (Kredo, M., 2006)

2. I.V. Avdulova, Tekhnologiya vizualizacii uchebnoj informacii https://multiurok.ru/files/tiekhnologhiia-vizualizatsii-uchiebnoi-informatsii.html

3. R. Arnhejm, Novye ocherki po psihologii iskusstva (Prometej, M., 2014)

4. S. Blejk, S. Pejp, M.A. CHoshanov, Pedagogika 5, 85-90 (2004)

5. B.M. Velichkovskij, Sovremennaya kognitivnaya psihologiya (MGU, M., 2012)

6. A.A. Verbickij, Aktivnoe obuchenie v vysshej shkole: kontekstnyj podhod. (Vyssh. shk., M., 2011)

7. V.P. Zinchenko, N.Y.Vergiles, Issledovanie deyatel'nosti zritel'noj sistemy (Izd-vo MGU, M., 2000)

8. G.V. Lavrent'ev, N.B. Lavrent'eva, N.A. Neudahina, Innovacionnye obuchayushchie tekhnologii v professional'noj podgotovke specialistov (BGU, Barnaul, 2009)

9. A.G. Raputo, III Vserossijskaya nauchno-prakticheskaya Internet-konferenciya «Innovacionnye napravleniya $v$ pedagogicheskom obrazovanii»s mezhdunarodnym uchastiem (Moskva)

10. I.V. Robert, S.V. Panyukova, A.A. Kuznecov, A.Y. Kravcova, Informacionnye $i$ kommunikacionnye tekhnologii v obrazovanii (Aspekt-Press, M., 2016)

11. G.K. Selevko, Sovremennye obrazovatel'nye tekhnologii (Narodnoe obrazovanie Moskva, 2018)

12. I.A. Truhan, D.A. Truhan, Uspekhi sovremennogo estestvoznaniya 10, 113-115 (2013)

13. R.E. Mayer, Multimedia learning (Cambridge University Press. New York, 2001) 